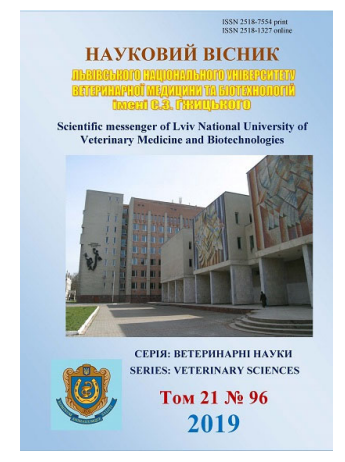

\author{
Науковий вісник Львівського національного університету \\ ветеринарної медицини та біотехнологій імені С.3. Гжицького. \\ Серія: Ветеринарні науки
}
Scientific Messenger of Lviv National University of Veterinary Medicine and Biotechnologies. Series: Veterinary sciences

UDC 577.1:616-006

\title{
Glutathione transferase and mammary tumors
}

\author{
O.M. Fedets, I.M. Kurlyak
}

Stepan Gzhytskyi National University of Veterinary Medicine and Biotechnologies Lviv, Ukraine

Article info

Received 04.11.2019

Received in revised form 10.12.2019

Accepted 11.12.2019

Stepan Gzhytskyi National University of Veterinary Medicine and Biotechnologies Lviv,

Pekarska Str., 50, Lviv, 79010, Ukraine.

Tel.: +38-067-411-14-46

E-mail:fedets@lvet.edu.ua
Fedets, O.M., \& Kurlyak, I.M. (2019). Glutathione transferase and mammary tumors. Scientific Messenger of Lviv National University of Veterinary Medicine and Biotechnologies. Series: Veterinary sciences, 21(96), 164-170. doi: 10.32718/nvlvet9629

The analysis of publications from the last 5 years is presented in this review. These articles describe the relationship of glutathione transferase (GST) with mammary tumors. Most of these works are dedicated to investigating the genotypic relationship between GST and neoplasms in human. The most common are single nucleotide polymorphism of GSTP1 Val105Ile (rs1695) and gene deletions GSTM1 and GSTT1. Several publications describe polymorphisms of GSTM3(rs4970737), GSTM4 and GSTA5. These polymorphisms (especially GSTP1 Val105Ile) are associated with the risk of mammary tumors, overall survival and relapse in patients of some ethnic groups. This is as a result of reduced enzymatic activity of GST and disturb of ability to detoxify substrates. Some studies demonstrate that single nucleotide polymorphism of GSTP1 Val105IIe is associated with a better response to chemotherapy and overall survival of patients, but no association with genotypes of GSTM1 and GSTT1. The injections of carcinogenic compounds into the tissue of mammary gland or its feeding to rats leed to decrease of GST activity and to development of tumors. The increased expression of GST in breast cancer cell lines leeds to increase of the resistance of these cells against various chemical compounds therefore the enzyme catalyzes the binding of these compounds to glutathione and this prevent their negative effects and is necessary for the formation of conjugates. Such increased expression of GST indicates on the resistance of breast cancer cell lines in particular to the action of drugs, which reduces their therapeutic effect. This is shown on cell lines BT474, MCF-7, MCF-7/ADR, MCF-7/ADR-1024, MCF-10A, MDA-MB-231, MDA-MB-468 and T47D. Chemical compounds (including antitumor drugs), that reduce the activity and/or expression of GST, can have a cytotoxic effect on these cells. Mammary tumors associated with epigenetic changes that do not change the sequence of nucleotides in GST genes. The methylation of the GSTP1 promoter decreases an expression of protein in mammary tissue and increases a risk of cancer in different ethnic groups. Compounds increase the level of expression of genes when they are able to lower the level of methylation or to affect demethylation. Polymorphisms of GST genes, their association with response to chemotherapy and overall survival of patients, expression of GST and it dependence on the action of anticancer drugs, methylation of GST promoter are associated with diagnosis, prognosis, and treatment of mammary neoplasms.

Key words: glutathione, polymorphism, breast, cancer.

\section{Глутатіонтрансфераза та пухлини молочної залози}

\author{
О.М. Федець, І.М. Курляк
}

Львівський національний університет ветеринарної медицини та біотехнологій імені С.3. Гљищького, м. Львів, Украӥна

В огляд представлений аналіз публікацій за останні 5 років по вивченню взаємозв'язку глутатіонтрансферази (GST) з пухлинами молочної залози. Більшість з них стосуються людини і присвячені дослідженню генотипової залежності між GST та иими новоутвореннями. Серед поліморфізмів найчастіше зустрічаються однонуклеотидний поліморфізм GSTP1 Val105Ile (rs1695) $i$ делеції генів GSTM1 та GSTT1, є окремі публікацї про поліморфізми GSTM3 (rs4970737), GSTM4 і GSTA5. Ці поліморфізми (особ- 
ливо GSTP1 Val105Ile) пов'язані з ризиком раку молочної залози, загальним виживанням та рецидивами у хворих в окремих етнічних групах внаслідок пониження ензиматичної активності і порушення здатності до детоксикації субстратів. Окремі дослідження вказують, щчо однонуклеотидний поліморфізм GSTP1 Val105IIе пов'язаний з кращою реакиією на хіміотерапію та високим загальним виживанням хворих. Проте не виявлено такого зв'язку з генотипами GSTM1 i GSTT1. B результаті ін'єкиій, або згодовування канцерогенних сполук в тканинах молочної залози шурів значно понижується активність GST $i$ розвиваються новоутворення. Підвищена експресія GST в культурах клітин молочної залози надає стійкості иим клітинам до дії різних хімічних сполук тому, щчо ензим каталізує зв'язування цих сполук з глутатіоном і ие запобігає їх негативному впливу, та є необхідним виведення з клітин утворених кон'югатів. Така підвищена експресія GST в культурах клітин раку молочної залози свідчить про підвищення стійкості цих клітин, зокрема до дї лікарських препаратів, цзо зменшує їх терапевтичних ефект. Це показано на культурах клітин BT474, MCF-7, MCF-7/ADR, MCF-7/ADR-1024, МCF-10A, MDA-MB-231, МDA-MB-468 і Т47D. Хімічні сполуки, які понижують активність та/або експресію GST, зокрема протипухлинні препарати, здатні проявляти циттотоксичний ефект на ияі клітини. Новоутворення молочної залози пов'язані також з епігенетичними змінами при яких не змінюється послідовність нуклеотидів в генах GST. В результаті метилювання промотора GSTP1 понижується експресія протеїну в тканині молочної залози і підвишується ризик раку в різних етнічних груп. Сполуки, які здатні понизити рівень метилювання, або впливають на деметилювання, підвищують рівень експресії цьього гену. Поліморфізми окремих генів GST, їх зв'язок з реакцією на хіміотерапію $і$ загальним виживання хворих, рівень експресї GST та ї̈ залежність від дї протипухлинних препаратів, метилювання промотора GST пов'язані з діагностикою, прогнозом розвитку та лікуванням новоутворень молочної залози.

Ключові слова: глутатіон, поліморфізм, новоутворення, рак.

Глутатіонтрансфераза (ЕC 2.5.1.18; RX:glutathione R-transferase). Це група ензимів з широкою субстратною специфічністю. R може бути аліфатичною, ароматичною чи гетроциклічною групою, а $\mathrm{X}$ - сульфатною, нітрильною або галоїдною групою. Каталізують також приєднання аліфатичних епоксидів та ареноксидів до глутатіону (GSH), відновлення глутатіоном поліолнітрату до поліолу та нітрилу, певні реакції ізомеризації та взаємообміну дисульфіду (IUBMB Enzyme Nomenclature).

Вперше глутатіонтрансфераза (GST) була частково очищена з печінки щура і встановлені деякі її властивості ще у 1961 році (Booth et al., 1961). У ссавців виявлені різні класи цієї групи: А, К, М, О, Р, S, Т, Z та родина MAPEG (Hayes et al., 2005). Перша праця, у якій були представлені результати досліджень ензиму в організмів, які мали новоутворення, була опублікована у 1984 році (Balkwill et al., 1984). На сьогодні розвинувся напрямок по вивченню взаємозв'язку GST 3 новоутвореннями молочної залози, тобто увага дослідників зосереджена на ролі ензиму в патологічних процесах Представлена праця є оглядом публікацій за останні 5 років. Більшість 3 них стосуються людини і присвячені дослідженню генотипової залежності між $G S T$ та новоутвореннями молочної залози. Поліморфізм GST

У жінок з Китаю однонуклеотидний поліморфізм (SNP) GSTP1 Val105Ile (rs1695) асоціювався 3 підвищеним ризиком до раку молочної залози серед носіїв гетерозигот $\mathrm{A} / \mathrm{G}$ та $\mathrm{A} / \mathrm{G}+\mathrm{G} / \mathrm{G}$, ніж у гомозиготних носіїв $\mathrm{G} / \mathrm{G}$ порівняно 3 контролем А/А. Авторами була встановлена також різниця в асоціації між rs 1695 та раком молочної залози серед білих, африканців та азіатів, що можна пояснити різними етнічними ознаками цих груп населення (Pan et al., 2016).

У жінок з Сгипту, в результаті оцінки генетичного поліморфізму GSTP1 Val105Ile (rs1695), виявлена знижена частота алеля Val серед пацієнтів з раком молочної залози порівняно зі здоровими (22,9\% проти 32,5\%) (Al-Harras et al., 2016).

У жінок з Китаю 3 гетерозиготними поліморфізмами GSTP1 Val105Ile (rs1695) або катехол-Ометилтрансферази (rs4680) встановлена понижена ензиматична активність і порушена здатність до детоксикація субстратів. Однак активність іншого ензиму може зростати, як компенсаційний механізм, так, що у осіб, які були гетерозиготними або для GSTP1, або для катехол-О-метилтрансферази не встановлено підвищеного ризику раку молочної залози. Подвійні гетерозиготні генотипи для GSTP1 і для катехол-Ометилтрансферази одночасно мали більш високий ризик раку молочної залози. Це пояснюється тим, що у осіб, які були двогетерозиготними як для катехол-Ометилтрансферази, так і для GSTP1 може бути порушений компенсаційний механізм. Встановлено, що чим більша кількість варіантів алелів GSTP1 і катехол-О-метилтрансферази, тим сильніше зменшується здатність до детоксикації субстратів, що призводить до підвищення ризику раку молочної залози. Тобто комбінація алелей GSTP1 та катехол-Ометилтрансферази пов'язана з ризиком раку молочної залози. Причому жінки з гомозиготним генотипами для GSTP1 або катехол-О-метилтрансферази мали більш високий ризик раку молочної залози, ніж особи 3 генотипами дикого типу. У досліджуваних пацієнтів не виявлено зв'язку поліморфізму GSTM3 (rs4970737) з раком молочної залози (Qiu et al., 2019).

За результатами досліджень серед жінок популяції Мізо в північно-східній Індії встановлено, що поліморфізм GSTP1 Val105Ile (rs1695) пов'язаний iз сприйнятливістю до раку молочної залози, проте не виявлено такого зв'язку для поліморфізму GSTP1 Val114Ala (rs1138272). Суттєво підвищений ризик раку молочної залози у жінок з делецією гомозиготних генів GSTM1 та/або GSTT1 і на це впливало також споживання копченого м'яса та овочів (Kimi et al., 2016).

За даними мета-аналізу, у якому було проаналізовано результати досліджень 10067 хворих, та 12276 здорових жінок, не встановлено суттєвої асоціації нульового поліморфізму GSTMI та GSTT1 з ризиком раку молочної залози. Якщо врахувати етнічну приналежність, то ризик раку молочної залози був більший для азіатів, проте не виявлено значної асоціації для білих, або змішаної етнічної групи. Поліморфізм GSTP1 Val105Ile (rs1695) не був пов'язаний з ризиком 
раку молочної залози у загальний групі. Проте він може збільшити ризик раку молочної залози для білих, але не для азіатів (Song et al., 2016).

Не виявлено взаємозв'язку між ризиком раку молочної залози у жінок з Йорданії та делеціями генів GSTT1 і GSTM1 та поліморфізмом гена GSTP1 Val105Ile (rs1695). Проте є припущення що поєднання між поліморфізмами GSTM1 та GSTP1 може бути пов'язане з розвитком і прогресуванням цього захворювання (Al-Eitan et al., 2019).

Період виживання у жінок з раком молочної залози був на 6,2 і 8,1 місяців довший, якщо у них були присутні генотипи GSTT1 і GSTM1, ніж у тих в кого були нульові генотипи. Проте поліморфізм GSTP1 Val105Ile (rs1695) не був пов'язаний із загальним виживанням цих пацієнтів (Zhang et al., 2017).

При дослідженні генетичних поліморфізмів GST у жінок із північного сходу Мексики виявлено, що підвищений ризик раку молочної залози пов'язаний 3 поліморфізмом делеції гену GSTM1, асоціацій між генотипами GSTT1, GSTP1 та GSTM3 та ризиком новоутворення не спостерігалось (Jaramillo-Rangel et al., 2015).

Bansal et al. (2015) виявили, що нульові генотипи GSTM1 i GSTT1 мали захисний ефект для розвитку карциноми молочної залози, та що немає зв'язку між виживанням, рецидивом захворювання, факторами ризику і поліморфізмами генів GSTM1 та GSTT1.

Для діагностики раку молочної залози важливо також враховувати SNP-SNP взаємодії різних генів, які підтримують шляхи кон'югації GSH. За даними (Wang et al., 2017) взаємодії GSTM1, GSTM4, GSTP1 i GSTA5 були вищими в 1,5 рази при підвищеному ризику раку молочної залози.

Не встановлено зв'язку між комбінованим впливом поліморфізмів GSTT1 і GSTM1 на ризик раку молочної залози у жінок (Miao et al., 2019).

У жінок з імуногістохімічно позитивною експресією GSTP1 в тканинах пухлин молочної залози був кращий прогноз, ніж у жінок з негативною експресією. 3 вищою позитивною експресією GSTP1 була пов'язана нижча клінічна стадія захворювання (Chen et al., 2017).

GST та реакиія на хіміотерапію

За даними Li et al. (2018) GSTM1 не нульового генотипу відіграє захисну роль у прогресуванні раку молочної залози у жінок, якщо не проводили хіміотерапію. Такі пацієнти мали кращий результат виживання порівняно з аналогами дикого типу. Проте, якщо проводили хіміотерапію, то ефект був менший, тобто ці пацієнти мали меншу користь від хіміотерапіï.

При дослідженні генотипів GSTM1 0/1, GSTT1 0/1 та GSTP1 Val105IIe (rs1695) у жінок з Китаю, яким діагностували рак молочної залози, встановлено, що генотип G/G GSTP1 Val105IIe (rs1695) був пов'язаний 3 кращою реакцією на хіміотерапію та високим загальним виживанням (Yuan et al., 2015).

Подібні дослідження в жінок з регіону внутрішня Монголія в Китаї, яким діагностували рак молочної залози, показали, що пацієнти 3 генотипом G/G GSTP1 Val105Ile (rs1695) та нульовим генотипом GSTM1, швидше за все, мали слабку реакцію на хіміотерапію і у них встановлено кореляцію із скороченням загального виживання (Wang \& Huang, 2015).

У дослідженнях Wang et al. (2015) нульовий генотип GSTM1 також асоціювався з кращою реакцією на хіміотерапію. Однак не спостерігали суттєвого зв'язку між поліморфізмами GSTT1 та GSTP1 і реакцією на хіміотерапію та загальним виживанням у пацієнтів із раком молочної залози.

У мета-аналізі 7506 пацієнтів не було виявлено суттєвого зв'язку між поліморфізмом GSTP1 та пухлинною реакцією на хіміотерапію. Поліморфізм GSTP1 був пов'язаний з підвищеною токсичністю, особливо у пацієнтів, які отримували хіміотерапію та були оперовані. Не виявлено асоціації між поліморфізмом GSTP1 та токсичністю внаслідок променевої терапії та хірургічного втручання. GSTP1 відіграє роль у зниженні токсичності паціснтів, які отримують променеву терапію в результаті якої утворюються активні форми кисню, проходить пероксидація ліпідів і клітин зазнають окисного стресу (Ma et al., 2017).

За даними імуногістохімічного аналізу GSTP1 не був достатнім маркером для прогнозування терапевтичного ефекту хіміотерапії ерибуліном у жінок 3 метастатичним раком молочної залози (Kashiwagi et al., 2017).

Тканини пухлин молочної залози людини мали підвищену стійкість до дихлорацетату (використовується для протиракової терапії) в результаті підвищеної експресії GSTZ1, яка перетворює дихлорацетат до його неактивного метаболіту гліоксилату (Jahn et al., 2016). Підвищена експресія GST у тканинах пухлин молочної залози, порівняно із здоровою тканиною, виявлена також методом 2D-електрофорезу (Al-Dhabi et al., 2016).

У тканині молочної залози щурів в результаті ін'єкцій в неї 7,12-диметилбензантрацену, активність GST знижувалась з 2,59 \pm 0,23 до 1,38 \pm 0,10 мкмоль 1-Cl-2,4-динітробензену/хв/мг протеїну та розвивались новоутворення (Deepalakshmi et al., 2016). Подібні результати отримали Balamurugan et al. (2017) 2,44 мкмоль 1-Cl-2,4-динітробензену/хв/мг протеїну проти 4,71 у контрольній групі, а етаноловий екстракт водоростей Hурnea musciformis зменшував негативний ефект 7,12-диметилбензантрацену шляхом відновлення антиоксидантної системи, що захищає молочну залозу від цього канцерогену. За даними Prasannakumari et al. (2017) внаслідок згодовування щурам 7,12-диметилбензантрацену активність GST у тканині молочної залози також понижувалась більше ніж вдвічі (з 43,742 \pm 5,27 до 21,300 \pm 5,86 мкмоль 1-Cl2,4-динітробензену/хв/мг протеїну).

GST в культурах клітин

Підвищена експресія GST в культурах клітин молочної залози надає стійкості цим клітинам до дії різних хімічних сполук тому, що ензим каталізує зв'язування цих сполук з GSH. Це запобігає їх негативному впливу i необхідне для виведення 3 клітин 
кон'югатів, які утворюються з GSH. Проте, підвищена експресія GST в культурах клітин раку молочної залози свідчить про підвищення стійкості цих клітин, зокрема до дії лікарських препаратів, що зменшує їх терапевтичних ефект.

Експресія GSTP в клітинах раку молочної залози знижувала кількість внутрішньоклітинного доксорубіцину шляхом детоксикації та деградації, викликаючи стійкість до нього. Зменшена експресія GSTP збільшувала внутрішньоклітинні кількості доксорубіцину в ракових клітинах, що вказує на внесок детоксифікації GSTP в доксорубіцинову стійкість (Zhang et al., 2018).

Експресія GSTP пов'язана з хіміорезистентністю у клітинах лінії раку молочної залози MCF-7 (Yang et al., 2017).

У клітинах MCF-7/ADR (стійкі до адріаміцину), порівняно з клітинами MCF-7, за даними вестерн-блот аналізу встановлена підвищена експресія GSTP1, що надає стійкості до адріаміцину (Wang et al., 2015). За даними Tsou et al. (2015) GSTP була надмірно експресована у клітинах MCF-7/ADR та MCF-7/ADR-1024 порівняно з МCF-7.

Клітини MCF-7/ADR мають більшу стійкість до дії адріаміцину, ніж MCF-7, за рахунок підвищеного рівня аутофагії в результаті взаємодії проліну123, лейцину160 і глутамату163 С-кінцевої ділянки GSTP1 3 p110 альфа-субодиницею фосфатиділінозитол-3кінази (Dong et al., 2019).

У клітинах аденокарциноми раку молочної залози MDA-MB-231 підвищувалась експресія GSTP1 під дією гіпертицину, в той же час в клітинах MCF-7 підвищувалась експресія глутатіонпероксидази (Theodossiou et al., 2017).

В умовах in vitro клітини раку молочної залози BT474 проявляли підвищену стійкість до тамоксифену шляхом підвищення рівня експресії GSTP (Li et al., 2017).

Рівень GSH був збільшений у клітинах лінії MDAMB-468 (потрійно-негативний рак молочної залози відсутня експресія генів рецепторів естрогену, прогестерону та тирозинової протеїнкінази erbB-2) порівняно з клітинами ВТ474. Це свідчить про метаболічну перевагу цих ракових клітин для усунення хіміотерапевтичних препаратів, що сприяє їх резистентності (Stewart et al., 2016).

Клітини МCF-10А, які були оброблені естрадіолом або 4-гідроксиестрадіолом мали в 7 разів збільшений рівень експресії GSTA1 мРНК, тобто GST мала захисний ефект (Yager et al., 2015).

Хімічні сполуки, які понижують активність та/або експресію GST здатні проявляти цитотоксичний ефект на клітини.

В умовах in vitro генетична або фармакологічна інактивація GSTP1 погіршувала виживання клітин i пухлиногенез в клітинах потрійно-негативного раку молочної залози (Louie et al., 2016).

Тритерпеноїди 3 Aglaia abbreviata проявляли цитотоксичний ефект на клітини лінії раку молочної зало- зи МCF-7, зокрема шляхом пониження експресії GSTP в цих клітинах (Cen et al., 2017).

Селенвмісні засоби також проявляли цитотоксичність по відношенню до клітин MCF-7 і знижували в них активність GST шляхом зв'язування з ії активним центром (Krasowska et al., 2019).

Екстракти Heracleum platytaenium, яка багата на фенольні сполуки та флавоноїди, інгібували активність GST на 38-47\% і мали цитотоксичний ефект на клітини лінії раку молочної золози T47D (позитивна експресія рецепторів естрогену) (Telkoparan et al., 2018).

В результаті інгібування GST, як в чутливих, так i в стійких до ліків клітинах MCF-7, посилювалась активність протиракових препаратів, зокрема ядоміцину (Hall et al., 2015).

\section{Метилювання промотора GST}

Новоутворення молочної залози пов'язані також 3 епігенетичними змінами (не змінюється нуклеотидна послідовність генів). Зокрема гіперметилювання промотора GSTP1 може бути використане як перспективний біомаркер раннього виявлення раку молочної залози.

Bhat et al. (2017) припускають, що раннє виявлення метилювання промотра може бути використане для виявлення пухлини та визначення медикаментозної терапії з врахуванням статусу рецепторів естрогену та прогестерону. У жінок, які проживали в Кашмірі, гіперметилювання промотора гена GSTP1 було пов'язане із зниженою експресією протеїну, який кодується даним геном, метастазуванням лімфатичних вузлів, та стадією пухлин молочної залози.

Гіперметилювання промотора GSTP1 у жінок 3 Китаю 3 доброякісними захворюваннями грудей було значно нижче, ніж у пацієнтів з раком грудей. Імуногістохімічний аналіз показав, що експресія протеїну GSTP1 була відсутня, або помітно знижувалась у більшості пухлин 3 метильованим GSTP1, тобто встановлена кореляція між метилюванням гена та зниженням рівня експресії протеїну (Wu et al., 2016).

За даними мета-аналізу що включав 1647 хворих i 559 здорових жінок встановлено, що при раку молочної залози була значно більша частота метилювання GSTP1. Етнічний аналіз показав, що існували статистично вірогідні асоціації між метилюванням промотора GSTP1 та підвищенням ризику раку молочної залози як серед білих так і азіатів, тоді як кореляція була сильнішою в азіатів, ніж у білих. Аберрантне метилювання GSTP1 частіше спостерігалось у пацієнтів 3 пізньою стадією пухлин, порівняно з ранньою стадією. 3 ризиком раку молочної залози корелювало аберрантне метилювання GSTP1 виявлене в тканинах та зразках крові. Метильована ДНК в крові мала пухлинне походження. Тобто метильований GSTP1 в крові може відображати зміни пухлини (Fang et al., 2016).

В умовах in vitro у клітинах лінії раку молочної залози МCF-7 куркумін інгібував метилювання промотора GSTP1 шляхом блокування каталітичного тіола- 
ту ДНК метилтрансферази 1 і це призводило до повторної експресії протеїну GSTP1 (Kumar et al., 2017).

Отриманий з рослин стероїдний лактон вітаферин А впливав на метилювання гену GSTM1 в клітинах раку молочної залози MCF-7 в умовах in vitro, та підвищував рівень експресії цього гену в резутьтаті його деметилювання в клітинах MDA-MB-231 (Szic et al., 2017).

\section{Висновки}

Поліморфізми окремих генів $G S T$, їх зв'язок з реакцією на хіміотерапію і загальним виживанням хворих, рівень експресії GST та ії залежність від дії протипухлинних препаратів, метилювання промотора $G S T$ пов'язані з діагностикою, прогнозом розвитку та лікуванням новоутворень молочної залози.

\section{Подяка}

Ця робота була фінансово підтримана Міністерством освіти і науки України (0118U003495).

\section{References}

Al-Dhabi, N.A., Srigopalram, S., Ilavenil, S., Kim, Y.O., Agastian, P., Baaru, R. et al. (2016). Proteomic analysis of stage-II breast cancer from formalin-fixed paraffin-embedded tissues. BioMed Research International, 2016, 1-6. doi: 10.1155/2016/3071013.

AL-Eitan, L.N., Rababah, D.M., Alghamdi, M.A., \& Khasawneh, R.H. (2019). Association of GSTM1, GSTT1 and GSTP1 polymorphisms with breast cancer among Jordanian women. OncoTargets and Therapy, 12, 7757-7765. doi: 10.2147/OTT.S207255.

Al-Harras, M.F., Houssen, M.E., Shaker, M.E., Farag, K., Farouk, O., Monir, R. et al. (2016). Polymorphisms of glutathione S-transferase 1 and toll-like receptors 2 and 9: Association with breast cancer susceptibility. Oncology Letters, 11(3), 2182-2188. doi: 10.3892/ol.2016.4159.

Balamurugan, M., Sivakumar, K., Anand, M.A.V., \& Suresh, K. (2017). Modulating effect of hypnea musciformis (red seaweed) on lipid peroxidation, antioxidants and biotransforming enzymes in 7,12dimethylbenz (a) anthracene. induced mammary carcinogenesis in experimental animals. Pharmacognosy Research, 9(1), 108-115. doi: 10.4103/09748490.187085 .

Balkwill, R., Mowshowitz, S., Seilman S.S., Moodie, E.M., Griffin, D.B., Fantes, K.H. et al. (1984). Positive interactions between interferon and chemotherapy due to direct tumor action rather than effects on host drugmetabolizing enzymes. Cancer Research, 44(11), 52495255. https://www.ncbi.nlm.nih.gov/pubmed/6091873.

Bansal, V.K., Rajan, K., Sharma, A., Paliwal, P., Chaubal, G., \& Jindal, V. (2015). Prospective case-control study to evaluate the role of glutathione $\mathrm{S}$ transferases (GSTT1 and GSTM1) gene deletion in breast carcinoma and its prognostic significance. Indian Journal of Surgery, 77(3), 1067-1072. doi: 10.1007/s12262014-1152-0.

Bhat, A., Masood, A., Wani, K.A., Bhat, YA., Nissar, B., \& Khan, N.S. (2017). Promoter methylation and gene polymorphism are two independent events in regulation of GSTP1 gene expression. Tumor Biology, 39(4), 1-11. doi: 10.1177/1010428317697563.

Booth, J., Boyland, E., \& Sims, P. (1961). An enzyme from rat liver catalysing conjugations with glutathione. Biochemical Journal, 79(3), 516-524. doi: $10.1042 / \mathrm{bj} 0790516$.

Cen, J., Zheng, B.B., Bai, R.B., Zhang, L., Zhang, F., \& Zhang, X. (2017). Triterpenoids from Aglaia abbreviata exert cytotoxicity and multidrug resistant reversal effect in MCF-7/ADM cells via reactive oxygen species induction and P-glycoprotein inhibition. Oncotarget, 8(41), 69465-69476. doi: 10.18632/oncotarget.17287.

Chen, G.L., Zhang, H., Sun, L.S., Jiang, Y.L., Xu, Z., Gu, H.Z., et al. (2017). Prognostic significance of GSTP1 in patients with triple negative breast cancer. Oncotarget, 8(40), 68675-68680. doi: 10.18632/oncotarget.19824.

Deepalakshmi, K., \& Mirunalini, S. (2016). Efficacy of Pleurotus ostreatus (Jacq. Ex Fr.) P.kumm. on 7,12dimethylbenz(a)anthracene induced mammary carcinogenesis in female Sprague-Dawley rats. New Horizons in Translational Medicine, 3(2), 73-82. doi: 10.1016/j.nhtm.2016.06.002.

Dong, X.L., Yang, Y., Zhou, Y., Bi, X.W., Zhao, N.W., Zhang, Z.P., et al. (2019). Glutathione S-transferases P1 protects breast cancer cell from adriamycininduced cell death through promoting autophagy. Cell Death and Differentiation, 26 (10), 2086-2099. doi: 10.1038/s41418-019-0276-y.

Fang, C., Wei, X.M., Zeng, X.T., Wang, F.B., Weng, H., \& Long, X.H. (2015). Aberrant GSTP1 promoter methylation is associated with increased risk and advanced stage of breast cancer: a meta-analysis of 19 case-control studies. BMC Cancer, 15(920), 1-8. doi: 10.1186/s12885-015-1926-1.

Hall, S.R., Blundon, H.L., Ladda, M.A., Robertson, A.W., Martinez-Farina, C.F., \& Jakeman, D.L. (2015). Jadomycin breast cancer cytotoxicity is mediated by a copper-dependent, reactive oxygen species-inducing mechanism. Pharmacology Research \& Perspectives, 3(2), e00110. doi: 10.1002/prp2.110.

Hayes, J.D., Flanagan, J.U., \& Jowsey, I.R. (2005). Glutathione transferases. Annual Review of Pharmacology and Toxicology, 45, 51-88. doi: 10.1146/annurev.pharmtox.45.120403.095857.

IUBMB Enzyme Nomenclature https:/www.qmul.ac.uk/sbcs/iubmb/enzyme/EC2/5/1/ 18.html.

Jahn, S.C., Solayman, M.H.M., Lorenzo, R.J., Langaee, T., Stacpoole, P.W., \& James, M.O. (2016). GSTZ1 expression and chloride concentrations modulate sensitivity of cancer cells to dichloroacetate. Biochimica et Biophysica Acta - General Subjects, 1860(6), 1202-1210. doi: 10.1016/j.bbagen.2016.01.024.

Jaramillo-Rangel, G., Ortega-Martínez, M., Cerda-Flores, R.M., \& Barrera-Saldaña H.A. (2015). Polymor- 
phisms in GSTM1, GSTT1, GSTP1, and GSTM3 genes and breast cancer risk in northeastern Mexico. Genetics and Molecular Research, 14(2), 6465-6471. doi: $10.4238 / 2015$.

Kashiwagi, S., Fukushima, W., Asano, Y., Goto, W., Takada, K., Noda, S. et al. (2017). Identification of predictive markers of the therapeutic effect of eribulin chemotherapy for locally advanced or metastatic breast cancer. BMC Cancer, 17(604), 1-10. doi: 10.1186/s12885-017-3598-5.

Kimi, L., Ghatak, S., Yadav, R.P., Chhuani, L., Lallawmzuali, D., Pautu, J.L. et al. (2016). Relevance of GSTM1, GSTT1 and GSTP1 gene polymorphism to breast cancer susceptibility in Mizoram population, northeast India. Biochemical Genetics, 54(1), 41-49. doi: 10.1007/s10528-015-9698-5.

Krasowska, D., Iraci, N., Santi, C., Drabowicz, J., Cieslak, M., Kazmierczak-Baranska, J. et al. (2019). Diselenides and benzisoselenazolones as antiproliferative agents and glutathione-S-transferase inhibitors. Molecules, 24(16), 1-19. doi: 10.3390/molecules24162914.

Kumar, U., Sharma, U., \& Rathi, G. (2017). Reversal of hypermethylation and reactivation of glutathione $\mathrm{S}$ transferase pi 1 gene by curcumin in breast cancer cell line. Tumor Biology, 39(2), 1-8. doi: $10.1177 / 1010428317692258$.

Li, S., Lang, G.T., Zhang, Y.Z., Yu, K.D., Shao, Z.M., \& Zhang, Q. (2018). Interaction between glutathione Stransferase M1-null/present polymorphism and adjuvant chemotherapy influences the survival of breast cancer. Cancer Medicine, 7(9), 4202-4207. doi: 10.1002/cam4.1567.

Li, Y.H., Jiang, B.H., Zhu, H.B., Qu, X.F., Zhao, L.Q., Tan, Y.R. et al. (2017). Inhibition of long non-coding RNA ROR reverses resistance to Tamoxifen by inducing autophagy in breast cancer. Tumor Biology, 39(6), 1-8. doi: 10.1177/1010428317705790.

Louie, S.M., Grossman, E.A., Crawford, L.A., Ding, L., Camarda, R., Huffman, T.R. et al. (2016). GSTP1 is a driver of triple-negative breast cancer cell metabolism and pathogenicity. Cell Chemical Biology, 23(5), 567-578. doi: 10.1016/j.chembiol.2016.03.017.

Ma, J., Zhu, S.L., Liu, Y., Huang, X.Y., \& Su, D.K. (2017). GSTP1 polymorphism predicts treatment outcome and toxicities for breast cancer. Oncotarget, 8(42), 72939-72949. doi: 10.18632/oncotarget.18513.

Miao, L.F., Wang, X.Y., Ye, X.H., Cui, M.S., \& He, X.F. (2019). Combined effects of GSTM1 and GSTT1 polymorphisms on breast cancer risk: A MOOSEcompliant meta-analysis and false-positive report probabilities test. Medicine, 98(6), e14333. doi: 10.1097/MD.0000000000014333.

Pan, Z., Fu, Z., Song, Q., Cao, W., Cheng, W., \& Xu, X. (2016). Genetic polymorphisms and haplotype of hormone-related genes are associated with the risk of breast cancer in Chinese women. Genetics and Molecular Research, 15(2), 1-9. doi: 10.4238/gmr.15028640.

Prasannakumari, J.J., Padmam, P., \& Doss, V.A. (2017). Therapeutic effect of hydro-ethanolic extract of pothos scandens 1 on key carbohydrate metabolizing enzymes and xenobiotic marker enzymes in DMBA induced experimental mammary carcinoma. Indian Journal of Pharmaceutical Education and Research, 51(3), 418426. doi: 10.5530/ijper.51.3.70.

Qiu, J., Du, Z., Liu, J., Zhou, Y., Liang, F., \& Lu, Q. (2018). Association between polymorphisms in estrogen metabolism genes and breast cancer development in Chinese women: A prospective case-control study. Medicine, 97(47), e13337. doi: 10.1097/MD.0000000000013337.

Song, Z., Shao, C., Feng, C., Lu, Y., Gao, Y., \& Dong, C. (2016). Association of glutathione S-transferase T1, $\mathrm{M} 1$, and $\mathrm{P} 1$ polymorphisms in the breast cancer risk: a meta-analysis. Therapeutics and Clinical Risk Management, 12, 763-769. doi: 10.2147/TCRM.S104339.

Soto-Quintana, O., Zúñiga-González, G.M., RamírezPatiño, R., Ramos-Silva, A., Figuera, L.E., CarrilloMoreno, D.I. et al. (2015). Association of the GSTM1 null polymorphism with breast cancer in a Mexican population. Genetics and Molecular Research, 14, 13066-13075. doi: 10.4238/2015.

Stewart, D.A., Winnike, J.H., McRitchie, S.L., Clark, R.F., Pathmasiri, W.W., \& Sumner, S.J. (2016). metabolomics analysis of hormone-responsive and triple-negative breast cancer cell responses to paclitaxel identify key metabolic differences. Journal of Proteome Research, 15(9), 3225-3240. doi: 10.1021/acs.jproteome.6b00430.

Szic, K.S.V., Declerck, K., Crans, R.A.J., Diddens, J., Scherf, D.B., Gerhauser, C. Epigenetic silencing of triple negative breast cancer hallmarks by Withaferin A. Oncotarget, 8(25), 40434-40453. doi: 10.18632/oncotarget.17107.

Telkoparan, A.P., Tuglu, Y.B., \& Shomali, M.N. (2018). Anticancer, antioxidant properties and phenolic, flavonoid composition of Heracleum platytaenium plant methanolic extracts. Journal of Research in Pharmacy, 22(3), 396-404. doi: 10.12991/jrp.2018.79.

Theodossiou, T.A., Olsen, C.E., Jonsson, M., Kubin, A., Hothersall, J.S., \& Berg, K. (2017). The diverse roles of glutathione-associated cell resistance against hypericin photodynamic therapy. Redox Biology, 12, 191197. doi: 10.1016/j.redox.2017.02.018.

Tsou, SH., Chen, TM., Hsiao, HT., \& Chen, YH. (2015). A critical dose of doxorubicin is required to alter the gene expression profiles in MCF-7 cells acquiring multidrug resistance. PLoS ONE, 10(1), e0116747. doi: 10.1371/journal.pone.0116747.

Wang, J., Wang, T., Yin, G.Y., Yang, L., Wang, Z.G., \& $\mathrm{Bu}$, X.B. (2015). Glutathione S-transferase polymorphisms influence chemotherapy response and treatment outcome in breast cancer. Genetics and Molecular Research, 14(3), 11126-11132. doi: 10.4238/2015. September.22.6.

Wang, W., Xu, Z.Z., Costanzo, M., Boone, C., Lange, C.A., \& Myers, C.L. (2017). Pathway-based discovery of genetic interactions in breast cancer. PLoS Genetics, 13(9), e1006973. doi: 10.1371/journal.pgen.1006973.

Wang, X., \& Huang, Z.H. (2015). Predictive potential role of glutathione S-transferase polymorphisms in the prognosis of breast cancer. Genetics and Molecular 
Research, 14(3), 10236-10241. doi: 10.4238/2015. August.28.7.

Wang, Z.P., Liang, S., Lian, X., Liu, L., Zhao, S., \& Xuan, Q.J. (2015). Identification of proteins responsible for adriamycin resistance in breast cancer cells using proteomics analysis. Scientific Reports, 5(9301), 1-9. doi: 10.1038/srep09301.

Wu, L., Shen, Y., Peng, X.Z., Zhang, S.M., Wang, M., Xu, G.S. et al. (2016). Aberrant promoter methylation of cancer-related genes in human breast cancer. Oncology Letters, 12(6), 5145-5155. doi: 10.3892/ol.2016.5351.

Yager, J.D. (2015). Mechanisms of estrogen carcinogenesis: The role of E2/E1-quinone metabolites suggests new approaches to preventive intervention - A review. Steroids, 99(A), 56-60. doi: 10.1016/j.steroids.2014.08.006.

Yang, M.L., Li, Y.R., Shen, X.F., Ruan, Y., Lu, Y., \& Jin, X.S. (2017). CLDN6 promotes chemoresistance through GSTP1 in human breast cancer. Journal of
Experimental \& Clinical Cancer Research, 36(157), 1-15. doi: 10.1186/s13046-017-0627-9.

Yuan, P., Yuan, L., Xu, B.L., Wang, C.Z., Yang, H.Z., \& Li, Y. (2015). Predictive potential role of glutathione S-transferases polymorphisms in response to chemotherapy and breast cancer prognosis. Genetics and Molecular Research, 14(4), 16675-16681. doi: 10.18632/oncotarget.18513.

Zhang, J., Wu, Y., Hu, X.C., Wang, B.Y., Wang, L.P., Zhang, S. et al. (2017). GSTT1, GSTP1, and GSTM1 genetic variants are associated with survival in previously untreated metastatic breast cancer. Oncotarget, 8(62), 105905-105914. doi: 10.18632/oncotarget.22450.

Zhang, Z.Y., Lin, G.H., Yan, Y.J., Li, X., Hu, Y.B., Wang, J. et al. (2018). Transmembrane TNF-alpha promotes chemoresistance in breast cancer cells. Oncogene, 37(25), 3456-3470. doi: 10.1038/s41388-0180221-4. 